\title{
Penerapan Model Pembelajaran Inside Circle Dalam Meningkatkan Hasil Belajar IPS Siswa Kelas IV SD Inpres 7/83 Pacing Kecamatan Awangpone Kabupaten Bone
}

\author{
Makmur Nurdin ${ }^{1}$, Sitti Jauhar ${ }^{2}$, Abu Darwis ${ }^{3}$ \\ ${ }^{1,2,3}$ Program Studi PGSD Fakultas Ilmu Pendidikan Universitas Negeri Makassar \\ 1'makmur.nurdin@unm.ac.id \\ 2sitti.jauhar@unm.ac.id \\ 3abu.darwis@unm.ac.id
}

\begin{abstract}
The problem in this research is the lack of grade IV students' learning outcome in social study subject. The problem statement in this research is how does the implementation of inside outside circle learning model increase the social study learning outcomes of grade IV students in SD Inpres 7/83 Pacing, Awangpone, District of Bone? The objective of this research is to describe the implementation of inside outside circle learning model in increasing social study learning outcomes of grade IV students in SD Inpres 7/83 Pacing, Awangpone, District of Bone. The benefits of this research consist of theoritical and practical benefits. The research approach used in this research is Classroom Action Research (CAR). The research focus is the implementation of inside outside learning model in increasing the social study learning outcomes of grade IV students in SD Inpres 7/83 Pacing, Awangpone, District of Bone. Setting of the research held in SD Inpres 7/83 Pacing, Awangpone, District of Bone and the subjects are teacher and the grade IV active students in the even semester academic year 2015/2016 with the 16 numbers of students, 7 male students and 9 female students. The research design consists of fours steps starting from planning, applying, observing, and reflecting. The data collection techniques of this research were test and observation. The data analysis techniques used in this research are data reduction, data presentation, conclusion/verification. The result research can be concluded that the implementation of inside outside circle learning model can increase social study learning outcome of grade IV students in SD Inpres 7/83 Pacing, Awangpone, District of Bone. It can be seen from the increase of the percentages of students activity and grade in cycle 1 are in the category of moderate, whereas in cycle II in the category of good.
\end{abstract}

Keywords: learning model, students learning outcome

\section{PENDAHULUAN}

Pada dasarnya pendidikan adalah suatu proses untuk membantu manusia dalam mengembangkan diri sehingga mampu menghadapi segala perubahan dan permasalahan dengan sikap terbuka tanpa kehilangan identitas dirinya. Pendidikan secara umum mempunyai arti suatu proses kehidupan dalam mengembangkan diri tiap individu untuk dapat hidup dan melangsungkan kehidupan. Hal ini sejalan dengan tujuan pendidikan nasional berdasarkan UU No. 20 tahun 2003 tentang Sisdiknas Pada Bab II pasal 3 berbunyi sbb:

Pendidikan nasional berfungsi mengembangkan kemampuan dan membentuk watak serta peradaban bangsa yang bermartabat dalam rangka mencerdaskan kehidupan bangsa, bertujuan untuk berkembangnya potensi peserta didik agar menjadi manusia yang beriman dan bertakwa kepada Tuhan Yang Maha Esa, berakhlak mulia, sehat, berilmu, cakap, kreatif, mandiri, dan menjadi warga negara yang demokratis serta bertanggung jawab.

Mencermati fungsi dan tujuan pendidikan nasional tersebut, untuk pengimplementasiannya diperlukan suatu proses pelaksanaan. Ilmu Pengetahuan Sosial (IPS) salah satu mata pelajaran khususnya di Sekolah dasar yang dapat mengimplementasikan sebagian tujuan pendidikan Nasional tersebut. Sebagaimana yang tertuang dalam Kurikulum Tingkat Satuan Pendidikan (KTSP) tahun 2006, terdapat mata pelajaran IPS yang bertujuan:

(1)Mengenal konsep-konsep yang berkaitan dengan kehidupan masyarakat dan lingkungannya. (2) memiliki kemampuan dasar untuk berpikir logis dan kritis, rasa ingin tahu, inkuiri, memecahkan masalah, dan keterampilan dalam kehidupan sosial. (3) 
memiliki komitmen dan kesadaran terhadap nilai-nilai sosial dan kemanusiaan. (4) memiliki kemampuan untuk berkomunikasi, bekerjasama dan berkompetisi dalam masyarakat yang majemuk, ditingkat lokal, nasional dan global.

Sejalan dengan itu Menurut Djahiri dan Ma'mun (Gunawan, 2011: 17) berpendapat bahwa :" IPS atau studi sosial konsepkonsepnya merupakan konsep pilihan dari berbagai ilmu lalu dipadukan dan diolah secara didaktis-pedagogis sesuai dengan tingkat perkembangan siswa". Ilmu Pengetahuan Sosial (IPS) menjadi suatu mata pelajaran yang dapat mengantarkan siswa untuk dapat menjawab masalah-masalah mendasar tentang individu, masyarakat, pranata sosial, problem sosial, perubahan sosial, dan kehidupan masyarakat berbangsa, dari waktu ke waktu. siswa diharapkan akan dapat menjawab pertanyaan tersebut di atas melalui substansi Ilmu Pengetahuan Sosial yang telah dirancang secara sistematis dan komprehensif. Dengan demikian, Ilmu Pengetahuan Sosial diperlukan bagi siswa dalam proses menuju kedewasaan dan mencapai keberhasilan dalam kehidupan di masyarakat dikelak kemudian hari. Ilmu Pengetahuan Sosial mengkaji seperangkat peristiwa, fakta, konsep, dan generalisasi yang berkaitan dengan isu sosial.

Ilmu Pengetahuan Sosial merupakan bidang studi di sekolah dengan tujuan mengembangkan pengetahuan, sikap, dan keterampilan sosial dalam bentuk konsep dan pengalaman belajar yang dipilih atau terorganisir dalam rangka kajian ilmu sosial.Berdasarkan pendapat tersebut di atas, upaya yang dilakukan untuk pencapaian tujuan ilmu pengetahuan sosial dikembangkan terus menerus seperti penyempurnaan kurikulum, sebab kurikulum merupakan unsur yang amat penting dalam mencapai tujuan pendidikan baik tujuan pendidikan nasional maupun pendidikan dasar. Dalam pembelajaran IPS diharapkan siswa mampu berpikir kritis dan logis, berkomunikasi, kerjasamaa dalam memecahkan sebuah masalah dan memiliki keterampilan dalam kehidupan sosial dan kesadaran terhadap nilai-nilai sosial, agar nantinya hasil belajar siswa dapat meningkat. Selain itu upaya yang dilakukan untuk dapat meningkatkan hasil belajar siswa pada mata pelajaran ilmu pengetahuan sosial yaitu peran guru dalam memilih strategi, pendekatan, model, ataupun model pembelajaran dan pengelolaan kelas, penyediaan buku ajar serta penyediaan media pembelajaran. Namun kenyataan dilapangan tidak sesuai dengan harapan, hal ini didasarkan dari hasil pra penelitian yang dilakukan sebelum penelitian dilaknakan.

Hasil pengamatan atau observasi pada tanggal 6-7 Juni 2016 di SD Inpres 7/83 Pacing Kecamatan Awangpone Kabupaten Bone, ditemukan bahwa siswa masih sulit memahami materi pelajaran IPS. Berdasarkan nilai ulangan semester siswa kelas IV dalam pelajaran IPS, dengan jumlah siswa 16, dimana 5 siswa mencapai ketuntasan atau $31,25 \%$, sedangkan 11 siswa yang tidak mencapai ketuntasan atau $68,75 \%$ dari KKM yaitu 75. Melihat fenomena hasil belajar IPS yang terjadi pada siswa khususnya pada kelas IV SD Inpres 7/83 Pacing Kecamatan Awangpone Kabupaten Bone disebabkan oleh faktor guru dan siswa.

Adapun faktor guru yaitu; 1) guru kurang menekankan pentingnya kerjasama dalam kelompok, 2) guru kurang mengaktifkan siswa, 3) guru kurang memberikan penguatan dan motivasi kepada siswa. Selain itu faktor siswa yaitu 1) siswa kurang terlibat dalam proses pembelajaran, 2) minat dan motivasi siswa pada kegiatan pembelajaran rendah, 3) siswa tidak berani mengungkapkan pendapatnya. Jika permasalahan tersebut dibiarkan secara terus menerus, akan mempengaruhi atau berdampak pada hasil belajar siswa dalam pembelajaran IPS yang pada gilirannya secara terus menerus akan menurunkan hasil belajar siswa. Oleh karena itu, untuk memecahkan masalah tersebut di atas, peneliti bersama guru akan mengkolaborasi penyebab masalah-masalah yang ditemukan oleh peneliti untuk menentukan cara pemecahan atau penanggulangannya dengan menggunakan model pembelajaran Inside Outside Circle dalam meningkatkan hasil belajar IPS siswa kelas IV SD Inpres 7/83 Pacing Kecamatan Awangpone Kabupaten Bone.

Model pembelajaran Inside Outside Circle sangat efektif dalam meningkatkan potensi dan tingkat pemahaman pada siswa karena model pembelajaran Inside Outside Circle dapat digunakan untuk memberikan kesan mendalam pada proses belajar siswa karena pola belajarnya yang unik sehingga siswa mudah mengingat informasi yang akan dia sampaikan kepada teman pasangannya.

Menurut Shoimin (2014 
1) Tidak ada bahan spesifikasi yang dibutuhkan untuk strategi sehingga dapat dengan mudah dimasukkan ke dalam pelajaran,2) Kegiatan ini dapat membangun sifat kerjasama antar siswa,3) Mendapatkan informasi yang berbeda pada saat bersamaan.

Selain itu model pembelajaran Inside Outside Circle juga memberikan siswa banyak kesempatan untuk mengolah informasi dan meningkatkan keterampilan berkomunikasi. Model ini membuat proses pembelajaran menjadi menarik karena skenario pembelajarannya yang membagi siswa menjadi dua kelompok kemudian masing-masing kelompok membentuk lingkaran dalam dan lingkaran luar sehingga setiap siswa mempunyai pasangan dan saling berhadapan. Setiap pasangan itu saling berbagi informasi setelah berbagi informasi dengan pasangannya, siswa yang di lingkaran luar bergeser dan mendapat pasangan lain kemudian berbagi informasi lagi, begitu seterusnya sampai kembali ke pasangan awal. Model ini cocok digunakan dalam pembelajaran IPS karena pembelajaran IPS memiliki cakupan isi/materi yang cukup banyak sehingga memudahkan guru untuk membagi materi sesuai dengan siswa yang membentuk lingkaran, karena masing-masing anak membawa informasi yang berbeda untuk teman pasangannya, sehingga siswa dapat memahami keseluruhan materi secara utuh.

Berdasarkan uraian di atas maka peneliti dalam kesempatan ini melakukan sebuah Penelitian Tindakan Kelas (PTK) dengan judul Penerapan Model Pembelajaran Inside Outside Circle dalam meningkatkan hasil belajar IPS kelas IV SD Inpres 7/83 Pacing Kecamatan Awangpone Kabupaten Bone.

Berdasarkan latar belakang masalah di atas, maka rumusan masalah dalam penelitian ini adalah bagaimanakah penerapan model pembelajaran Inside Outside Circle dalam meningkatkan hasil belajar IPS siswa kelas IV SD Inpres 7/83 Pacing Kecamatan Awangpone Kabupaten Bone?. Secara garis besar prosedur penelitian ini mencakup empat tahapan yaitu Perencanaan (planning), Tindakan (action), Pengamatan (observing), dan Refleksi (reflecting).

\section{METODE PENELITIAN}

\section{a. Pendekatan Penelitian}

Penelitian ini dilakukan dengan menggunakan pendekatan kualitatif. Pendekatan ini bersifat deskriptif, artinya menggambarkan semua kejadian yang terjadi selama penelitian berlangsung. Pendekatan kualitataif memiliki beberapa ciri sebagaiman yang dirumuskan oleh Lincoln dan Guba (Moleong, 2014: 4-8) sebagai berikut :

1) Latar alami, 2) manusia sebagai alat, 3) metode kualitatif, 4) analisis data secara induktif, 5) teori dari dasar, 6) deskriptif, 7) lebih mementingkan proses dari pada hasil, 8) adanya batas yang ditentukan oleh fokus, 9) adanya kriteria khusus untuk keabsahan data, 10) desain yang bersifat sementara, 11) hasil penelitian dirundingkan dan disepakati bersama.

Adapun karakteristik penelitian kualitatif menurut (Sugiyono,2012: 13) sebagai berikut : 1) dilakukan pada kondisi yang alamiah,(sebagai lawannya adalah eksperimen), langsung ke sumber data dan peneliti adalah instrument kunci, 2) penelitian kualitatif lebih bersifat deskriftif. Data yang terkumpul berbentuk kata-kata atau gambar, sehingga tidak menekankan pada angka, 3) penelitian kualitatif lebih menekankan pada proses dari pada produk outcome, 4) penelitian kualitatif melakukan analisis data secara induktif, 5) penelitian kualitatif lebih menekankan makan (data balik yang teramati).

Memperhatikan ciri dan karakteristik tersebut, maka pendekatan kualitataif cocok diguankan dalam penelitian jenis tindakan kelas, sebab dalam penelitian tindakan kelas salah satu cirinya adalah lebih mementingkan proses dari pada hasil. Kemudian dalam pengolahan datanya dianalisis secara kualitataif tanpa menggunakan statistik.

\section{b. Jenis penelitian}

Jenis penelitian ini adalah Penelitian

Tindakan Kelas (PTK). Menurut (Suharsimi,2014 :3) bahwa "Penelitian Tindakan Kelas merupakan suatu pencermatan terhadap kegiatan belajar berupa sebuah tindakan, yang sengaja dimunculkan dan terjadi dalam sebuah kelas secara bersama".

Penelitian tindakan kelas memiliki karakeristik dirumuskan oleh (Muslich,2014: 45) "pelaksanaan tindakan dalam penelitian ini dilaksanakan secara berdaur (siklus) ulang". Apabila pada siklus I sudah bisa mencapai tujuan yang diinginkan maka langsung dapat ditarik kesimpulan, tetapi jika masih ada perbaikan, atau metode yang digunakan tidak berhasil maka dilanjutkan dengan tindakan selanjutnya.

Sehubungan dengan hal tersebut (Suharsimi,2014:58) berpendapat bahwa "penelitian tindakan kelas dilakukan dengan 
bertujuan memperbaiki atau meningkatkan mutu praktik pembelajaran".

Berdasarkan dari beberapa pendapat tersebut di atas, maka dalam penelitian tindakan kelas ini akan dilakukan secara berkolaborasi dengan guru kelas di SD Inpres 7/83 Pacing Kecematan Awangpone Kabupaten Bone dalam usaha memperbaiki proses pembelajaran untuk meningkatkan hasil belajar siswa.

\section{HASIL \& PEMBAHASAN \\ Pelaksanaan pembelajaran dengan} menggunakan model Inside Outside Circle dalam penelitian ini menggunakan delapan langkah diantaranya guru menyampaikan materi dengan menampilkan media, guru membagi siswa dalam 2 kelompok besar secara heterogen, guru membagikan LKS setiap kelompok, guru mengatur siswa membentuk lingkaran kecil menghadap keluar dan sebagian siswa lainnya membentuk lingkaran di luar lingkaran pertama menghadap ke dalam, guru mengarahkan siswa di lingkaran kecil tetap di tempat dan siswa di lingkaran besar bergeser satu atau dua langkah searah jarum jam, guru mengarahkan siswa di lingkaran besar membagi informasi, pergerakan baru dihentikan jika anggota kelompok lingkaran dalam dan luar sebagai pasangan asal bertemu kembali, guru bertanya jawab tentang informasi yang mereka peroleh melalui kegiatan lingkaran kecil lingkaran besar, dan guru membimbing siswa menyimpulkan pelajaran.

Upaya yang dilakukan untuk meningkatkan hasil belajar siswa tentang perkembangan teknologi adalah dengan menerapkan model Inside Outside Circledengan mengajak siswa secara bersamasama menyampaikan informasi dengan cara membentuk lingkaran kecil lingkaran besar.Dalam pembelajaran ini, Siswa merasa bahwa langkah-langkah yang dilakukan guru dalam mengajar dapat memotivasi siswa untuk cepat mengerti dan memahami materi pelajaran. Model pembelajaran Inside Outside Circle ini dipandang cukup optimal dalam membantu pencapaian tujuan pembelajaran. Hal ini terlihat dari hasil yang diperoleh oleh siswa dari setiap tindakan menunjukan peningkatan.

Hasil pengamatan yang telah dilakukan oleh pengamat/observer terhadap aktifitas siswa dan guru dalam pembelajaran menggunakan model Inside Outside Circle telah berjalan dengan baik di setiap siklus.
Dengan demikian belajar dengan menggunakan model pembelajaran Inside Outside Circle dapat mengaktifkan siswa dan mengurangi dominasi guru dalam menjelaskan.

Penggunaan LKS dalam setiap pembelajaran yaitu dengan tujuan agar dapat membantu siswa dalam menyampaikan informasi kepada kelompok lain. Selain itu, dengan LKS dapat membantu guru mengarahkan pemikiran siswa kearah munculnya jawaban yang diharapkan.. Guru memberikan dorongan kepada siswa agar senantiasa bekerja sama, saling membantu mengatasi kesulitan dan saling menghargai pendapat. Guru juga senantiasa memberikan bimbingan seperlunya kepada siswa yang mengalami kesulitan. Guru berusaha agar siswa sendiri mengkonstruksi pengetahuannya melalui kerja sama dan saling berdiskusi. Setelah pemberian LKS dilaksanakan maka guru memanggil siswa untuk membentuk lingkaran sesuai langkah-langkah yang ada di LKS. Penyampaian informasi berlangsung secara bergantian dan dimulai oleh kelompok lingkaran kecil setelah pasangan asal bertemu kembali giliran lingkaran besar menyampaikan informasinya sampai bertemu kembali dengan pasangan yang pertama. Kemudian guru membimbing siswa untuk menyimpulkan materi pelajaran. Setelah itu guru memberikan evaluasi untuk memgetahui kemampuan siswa yang dilaksanakan setiap pertemuan 2 pada siklus I dan siklus II. Melalui evaluasi hasil pada setiap pembelajaran, telah ditemukan bahwa dari siklus I ke siklus II diperoleh nilai tes siswa mengalami peningkatan. Berdasarkan kedua hal tersebut, dapat dikatakan bahwa pelaksanaan pembelajaran dengan model pembelajaran Inside Outside Circle dapat meningkatkan hasil belajar siswa dalam mata pelajaran IPS.

Berdasarkan presentasi yang dicapai siswa pada setiap akhir pembelajaran tersebut dari tes siklus I, dan tes siklus II menunjukan peningkatan yang baik dan dapat diketegorikan Baik (B). Hal ini dapat diinterpretasikan bahwa siswa sudah mengalami peningkatan hasil belajar dalam menyampaikan informasi secara bersamaan dengan cara membentuk lingkaran kecil lingkaran besar. Dengan meningkatnya hasil belajar siswa terhadap perkembangan teknologi mengindikasikan bahwa model pembelajaran Inside Outside Circle memungkinkan untuk dijadikan sebagai salah satu model pembelajaran dalam meningkatkan hasil belajar siswa dalam mata pelajaran IPS khususnya di SD. 


\section{KESIMPULAN \& SARAN}

Berdasarkan hasil temuan peneliti, maka hasil penelitian ini dapat disimpulkan bahwa ada 8 komponen model pembelajaran Inside Outside Circle sudah berjalan dengan baik dan dapat meningkatkan hasil belajar IPS siswa kelas IV SD Inpres 7/83 Pacing Kecamatan Awangpone Kabupaten Bone. Hal ini dibuktikan dengan hasil belajar yang dicapai siswa pada tes siklus I dengan kategori cukup (C) meningkat pada siklus II menjadi kategori baik (B).

\section{DAFTAR PUSTAKA}

Arikunto, Suharsimi. 2006. Penelitian Tindakan Kelas. Jakarta : Bumi Aksara.

Arikunto, Suharsimi dan Cepi Safruddin.2014. Evaluasi Program Pendidikan.Jakarta : Bumi Aksara

Depdiknas. 2006. Kurikulum Tingkat Satuan Pendidikan (KTSP).Jakarta:Departemen Pendidikan Nasional. 2003. Undang-Undang No. 20 Tahun 2003 tentang Sistem Pendidikan Nasional.

Gunawan, Imam. 2014. Metode Penelitian kualitatif Teori\& Praktik. Jakarta : Bumi Aksara

Gunawan, Rudi. 2011. Pendidikan IPS Filosofi, Konsep, dan Aplikasi. Bandung :

Alfabeta.

Huda, Miftahul. 2014. Model-Model Pengajaran dan Pembelajaran. Yogyakarta : Pustaka Belajar.

Jihad, Asep dan Haris, Abdul. 2013. Evaluasi Pembelajaran. Yogyakarta: Multi Pressindo.

Moleong, Lexy J. 1998. Metodologi Penelitian Kualitatif. Bandung : PT Remaja Rosdakarya.

Muslich, Masnur. 2014. Melaksanakan PTK Penelitian Tindakan Kelas itu mudah. Jakarta : PT Bumi Aksara.

Sapriya. 2015. Pendidikan IPS Konsep dan Pembelajaran.Bandung : Rosda.

Sinring, Abdullah dkk.2012. Pedoman Penulisan Skripsi Program S-1FIP UNM. Makassar: Fakultas Ilmu Pendidikan Universita Negeri Makassar.

Shoimin, Aris. 2014. 68 Model Pembelajaran Inovatif dalam Kurikulum2013. Yogyakarta : AR-Ruzz Media.
Sugiyono. 2012. Metode Penelitian Kualitatif Kuatitatif dan $R \& D$. Bandung :

Alfabeta

Supardan, Dadang. 2015. Pengembangan Ilmu Pengetahuan Sosial Perspektif, Filosofi, dan Kurikulum.Jakarta : Bumi Aksara.

Suprijono, Agus. 2014. Cooperatif Learning Teori \& Aplikasi Paikem. Yogyakarta : Pustaka Belajar

Susanto, Ahmad. 2013. Teori Belajar Pembelajaran disekolah Dasar. Jakarta : Kencana Prenada Media Group. 